\title{
THE WILDCAT HILL WILDERNESS AREA
}

People everywhere have recently become acutely aware of the dangers of envir mental deterioration. Ever-increasing human populations are taking over and poison so much of the earth's surface that in the next century an earth unfit for all hig forms of life is entirely possible.

Canadians necessarily share this concern. The Canadian Government, for exam is trying to prevent irreparable damage to the delicate ecosystems of the Arctic. $\mathrm{H}$ in southern Saskatchewan the grassland ecosystem, though more stable, is ea: plowed and destroyed. We have not yet been able to have any of it placed in the $r$ tive safety of a National Park.

The Saskatchewan Natural History Society has tried to develop an understand of the possibility of an environmental crisis. When Silent Spring was published 1962 we gave it a lengthy review because it clearly explained how persistent pois like DDT, accumulate at the top of food chains and how man is dumping hundr of chemicals into the environment without any knowledge of how this will af the total ecosystem of the earth.

We passed resolutions asking that more study and public hearings be held bef the draining of wetlands. Not only did there seem to be no need for the expansior cereal production but the drainage practice was leading to loss of valuable hab and the ever-increasing possibility of spring flooding in our valleys, villages and cit

Our Prairie Dog Sanctuary and our Maurice Street Sanctuary are two sr areas which we have managed to have designated as protected areas in which va. other than farming, forestry or mining are recognized. Other groups in other part Canada are also trying to protect small areas. These groups are now receiving 1 and encouragement from the Nature Conservancy and larger areas will be proter by the efforts of private Canadian citizens. The Editor, when attending the rer annual meeting of the Conservancy, was informed that this year officers of Conservancy would visit Saskatchewan to meet naturalists and talk of acquisitior natural areas. This effort is also helped by IBP-CT (International Biological Progr Conservation Terrestrial) which is not purchasing or providing money but whic is making detailed studies (check-sheets) of natural areas. These will be avail le internationally and pressure can develop for the protection of every kind of hak it and living plant or animal. If you value an area and wish to have it protected bey d your own life time, you should write to your editor who is a director of $\mathrm{Na}: e$ Conservancy.

Individuals, whether property owners or not, can do much to help change ie climate of thinking regarding problems of the environment. They can write to $\mathrm{P}_{1}$ 1e Minister Trudeau and $\mathrm{Mr}$. J. Chrétien, Minister of Indian Affairs and Nort] $n$ Development pressing for another National Park. If concerned people do not exp is their views, there will never be a national park in the beautiful South Nahanni a a, N.W.T. If we do not write to our federal and provincial governments, there will $n$ ar be a National Grassland Park in Canada. At this moment you should be writin to the Secretary, Public Hearings Office, National and Historic Parks Branch, 10 Laurier Avenue West, Ottawa 4, Ontario to speak on behalf of Prince Albert Nati al Park. You should support the Park Policy and speak against the vested intel ts which want to open the park to more permanent housing, to industry and comme al development and to more highways and motor toboggans. Attend the public hear gs on the future of P.A. National Park on June 28 in Regina or June 30 in Prince Al st. Press the provincial government for public hearings before they drain new a: is, industrialize provincial parks, or open new areas for mines or lumbering or agricul :e.

Real evidence that the thinking on environment is changing is given this ar by the Saskatchewan Government which has long adhered to the multipurpose con st. The Clean Environment Bill will help to prevent the death of our own clear, c an rivers, of Lake Winnipeg which receiyes much of our water and of the oceans of he world. We are a part of one finite and fragile ecosystem and if we don't prote it there is no point in trying to preserve a few square miles on the prairies. Ser Id, the Saskatchewan Government announced the establishment of the Wildcat ill Wilderness Area, 40,000 acres in the Pasquia Hills, in which there will be no bering, no mining and no roads.

We congratulate our government on their forward-looking policies and urge 3 to continue developing anti-pollution regulations and to continue to act as leade: in the setting aside and protection of natural areas. 


\section{THE WILDCAT HILL WILDERNESS AREA}

\section{by Tom White, Regina}

On April 13, 1971, the Honourable J. Ross Barrie, Minister of Natural Resources, strongly supported by members of both sides of the house, announced in the Saskatchewan Legislature the creation of the Wildcat Hill Wilderness Area, the first of its kind so designated in the province. It is pertinent at this time to describe the park and some of the considerations concerned with its creation.

The Pasquia Hills are part of the rise between the first and second prairie steppes. (The first steppe extends as lowland marshes eastward to Hudson Bay.) The north and eastern slopes of the Pasquia and Porcupine Hills rise steeply from the muskegs. The Pasquia Hills rise approximately 1800 feet on the north slope reaching an elevation of 2740 feet at the highest point. From other directions, the hills, lacking the dramatic falls of the northern slopes, appear as a low, forested rise. They have a high rainfall, a moist atmosphere and therefore a more verdant flora than the drier prairies to the south. The area, in the words of the DNR news release "encompasses within its boundaries the headwaters of three streams-the Fir, Pasquia and Man Rivers all arise within a radius of one and one-halt miles. ... [The] protection of these headwaters is a vital element of the Wilderness Area. Bankside and Firhead Lakes, the Source of the Man and Fir Rivers, are in themselves a logical focal point of the area." Or every slope the rivers come tumbling down from the higher ground unti they become the slow-moving trout streams so prized by trout fishermen Some rivers have cut deep-sided ravines and canyons, and jack pin and spruce whirr as the wind sweep through the forest. The Man River curves gracefully around Wildcat Hil which rises spectacularly above the surrounding country. The central core

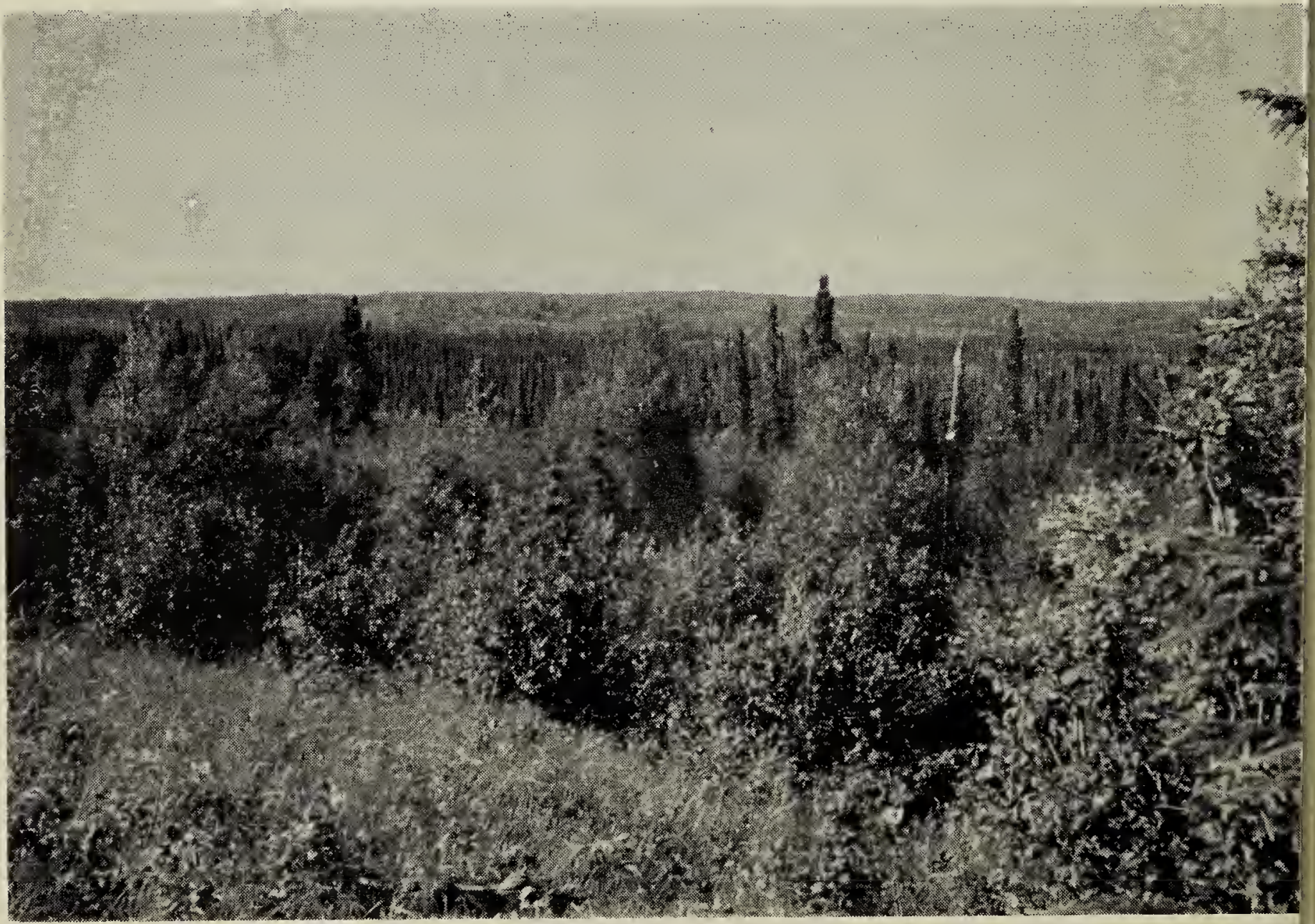

The view north from Wildcat Hill 
In 1690 Henry Kelsey became the first white man to penetrate Saskatchewan and as he journeyed from The Pas one of his first sights would have been the long blue line of the Pasquia Hills. It was not far from here that Kelsey became the first white man in North America to describe the grizzly bear.

Louis-Joseph La Vérendrye and Anthony Henday would have seen the hills when they ascended the Saskatchewan in 1749 and 1754 respectively. Samuel Hearne established Cumberland House in 1774 in sight of the northern slopes.

When the Franklin Expedition wintered at Cumberland House in 1820, they sent Lt. Hood to draw "a moose deer" in the "Basquia Hills" from which area Cumberland House got most of its meat. A chapter in Franklin's book Journey to the Polar Seas contains both Lt. Hood's accounts and an illustration of the interior of an Indian teepee near the hills. Before

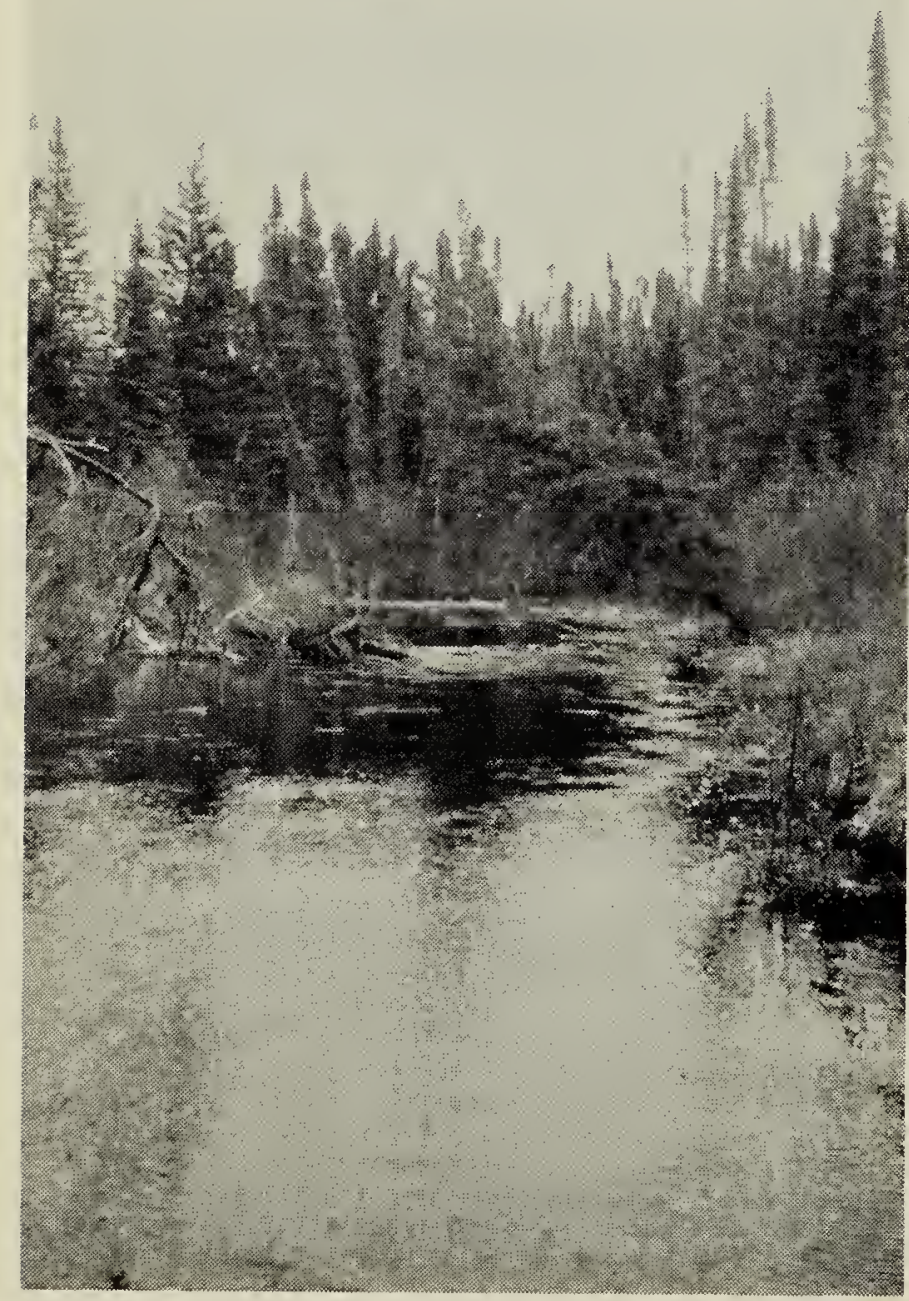

Fir River, a good trout river

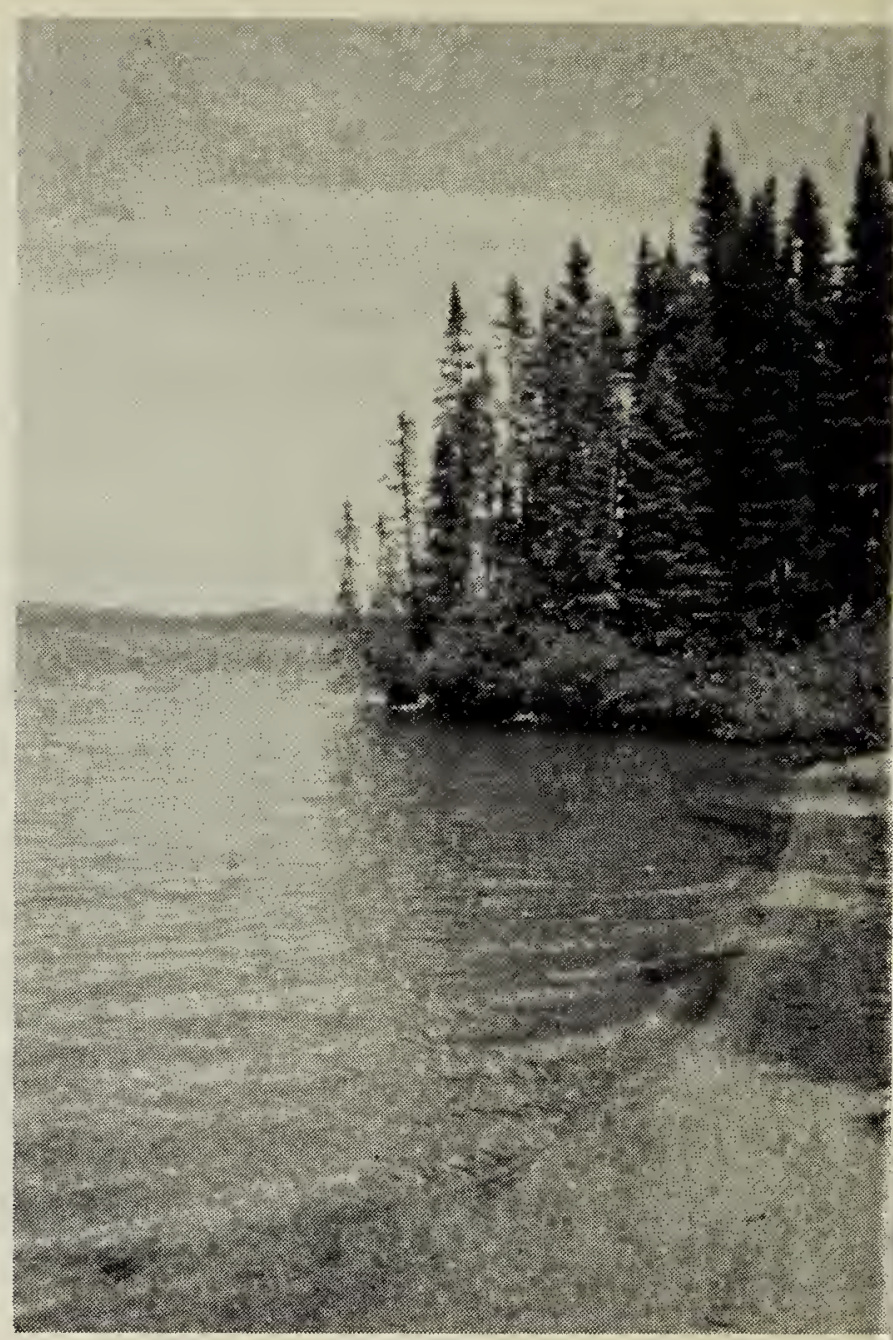

Sandy shore of

Bankside Lake

the First World War, the Finger Lumber Company (in 1918 purchased by the Wintons and renamed The $\mathrm{Pa}^{2}$ Lumber Company) obtained a concession and floated logs down the Carrot River to their mill at The Pas. Judg. ing by the size of the stumps remaining there were very large trees in the hills originally, although operations ceased when the economically access. ible timber was removed. In Septem ber 1916 the immense Pasquia Fores Preserve became also the Pasquic Game Preserve. In 1940 a great fir burned for months on top of the hill: and, though thirty years have elapsed the dead falls still indicate the resul of this prolonged blaze. In the 1940 ' and '50's the first highway reacher Hudson Bay and in the 1960's th Otosquen Road (now Highway 109) across the Hills to The Pas was con structed. Highway 163 has been re cently constructed to the north of th Hills thereby making them accessibl around their perimeter for the firs time. 
The creation of the Wildcat Hill ilderness area has been the result of le work of a great many organizaons and individuals. The Regina atural History Society held a series field trips in the Hills the report which appeared in the Blue Jay in 964. The Saskatchewan Natural Hisry Society passed in 1965 the first ficial motion asking for a wilderness rea to be set aside and this was in irn supported by the Saskatchewan Vildlife Federation in 1965 and 1970. Ir. Mazure brought the matter to the ttention of the provincial Homeoming Committee and obtained the upport of the town of Hudson Bay. he sympathetic co-operation of the impson Lumber Company in withrawing its cutting rights also contri- buted in making the proposal possible. Indeed, fishermen, canoeists, naturalists, biologists, as well as many interested private citizens, have all assisted in creating a favourable climate of public opinion. Most important is the foresighted attitude of the Department of Natural Resources without which no progress could have been made.

The fascination of the Pasquia Hills, then, lies in their wild and inaccessible nature and in the knowledge that so many animal and plant species live within them. With the establishing of this first wilderness area all conservationists will experience a sense of pride and a further stimulus to work for the setting aside of other similar areas in the province.

\section{THE PROPOSED ARCTIC INTERNATIONAL WILDLIFE RANGE}

\section{by Everett B. Peterson, Vancouver, B.C.}

Members of the Saskatchewan Natral History Society will be interested i following the outcome of the confernce on the Arctic International Wildife Range because in the manner in which it was structured, its goals, and he various follow-up steps this conerence could serve as a model for ringing together the interests of conervationists, industrialists and govrnments and for developing an aproach to land management that all an endorse. While we must await the utcome of proposals from this conerence, it is evident that it represented in important first step toward desigation of an Arctic International Wildlife Range in an area that still ossesses, comparatively unchanged, in unusually wide range of landforms ind native life, including indigenous eople. Of particular importance are he caribou, currently numbering in excess of 100,000 , that have an interhational migration pattern in the area proposed for a Wildlife Range. The habitat of these large herds is still intact but their future cannot be guaranteed without a substantial range that is permanently protected in both the Yukon Territory and Alaska.

The conference was held at Whitehorse, Yukon Territory, on October 21 and 22, 1970; it was hosted by the Yukon Conservation Society and was under the general chairmanship of Dr. A. R. Thompson, Faculty of Law, University of British Columbia. Conference delegates, 50 from Canada and 14 from the United States, included representatives of the native peoples, Federal and Territorial governments, industries, universities, and several conservation organizations. The broad objective of the conference was to explore ways by which the diverse interests in the extreme northern part of the Yukon Territory might be adjusted to allow designation of a wildlife range in Canada that would be continuous with Alaska's Arctic Wildlife Range. 